
\title{
Leadership styles and personal and professional profile of
intensive care unit nurses*
}

\author{
Estilos de liderança e perfil profissional de enfermeiros em Unidade de Terapia Intensiva \\ Estilos de liderazgo y perfil profesional de enfermeros de una Unidad de Cuidados Intensivos
}

\begin{abstract}
Objective: To verify the relation between leadership styles and personal and professional profile of a nurse facing another team member when performing ICU patient care. Methods: Samples were collected on seven nurses and seven practical nurses working as partners. Throughout three months, the nurses were inquired about the leadership style applied when the practical nurse, under their assessment, performed ICU patient care. Results: Persuasion style prevailed among other styles, followed by determining and sharing between leaders and their subordinated team member. Conclusion: In this ICU, nurses stand out due to their persuading situational leadership style where they explain their decisions and provide the opportunity for clarification to the subordinated team. No relation between the nurses' leadership style and their professional and personal profile was shown.
\end{abstract}

Keywords: Leadership; Intensive care units; Nurses, male; Nurses; Professional practice

\section{RESUMO}

Objetivo: Verificar a associação entre estilos de liderança e perfil pessoal e profissional do enfermeiro diante de um membro de sua equipe na realização de cuidados aos pacientes na UTI. Métodos: A amostra foi constituída por sete enfermeiros e sete técnicos de enfermagem que formaram duplas. Durante três meses os enfermeiros foram questionados sobre qual estilo de liderança seria adotado quando o técnico de enfermagem, sob sua avaliação, prestasse cuidados aos pacientes admitidos na UTI. Resultados: Houve predominância dos estilos persuadir, seguido de determinar e compartilhar dos líderes para com os liderados. Conclusão: Nesta UTI, os enfermeiros destacam-se pelo estilo persuado de liderança situacional onde explicam suas decisões e dão oportunidade de esclarecimentos à equipe de liderados. Não houve relação entre os estilos de liderança dos enfermeiros e seu perfil pessoal e profissional.

Descritores: Liderança; Unidades de terapia intensiva; Enfermeiros; Enfermeiras; Prática profissional

\section{RESUMEN}

Objetivo: Verificar la asociación entre estilos de liderazgo y perfil personal y profesional del enfermero frente a un miembro de su equipo en la realización de cuidados a pacientes de la UCI. Métodos: La muestra estuvo constituída por siete enfermeros y siete técnicos de enfermería que formaron parejas. Durante tres meses los enfermeros fueron cuestionados respecto al estilo de liderazgo que adoptaría cuando el técnico de enfermería, bajo su evaluación, prestase cuidados a los pacientes admitidos en la UCI. Resultados: Hubo predominio de los estilos persuadir, seguido de determinar y compartir de los líderes para con los liderados. Conclusión: En esta UCI, los enfermeros se destacan por el estilo de persuación de liderazgo situacional en el cual explican sus decisiones y dan oportunidad de aclaraciones al equipo de liderados. No hubo relación entre los estilos de liderazgo de los enfermeros y su perfil personal y profesional.

Descriptores: Liderazgo; Unidades de cuidados intensivos; Enfermeros; Enfermeras; Práctica profesional

\footnotetext{
* This article is part of the Master's Degree Thesis presented to Universidade Federal de São Paulo - UNIFESP - São Paulo (SP), Brazil. "Leadership Styles on Intensive Care Units and their relation with nursing work load"

${ }^{1}$ Master, Member of the Health Services Administration and Nursing Management Research and Studies Group - GEPAG of Universidade Federal de São Paulo - UNIFESP - São Paulo (SP), Brazil.

${ }^{2}$ PhD, Associate Professor of Applied Administration to the Nursing Department of Universidade Federal de São Paulo - UNIFESP - São Paulo (SP), Brazil.

${ }^{3}$ PhD, Associate Professor of Surgical-Clinic Nursing of the Nursing Department of Universidade Federal de São Paulo - UNIFESP - São Paulo (SP), Brazil.
} 


\section{INTRODUCTION}

In an Intensive Care Unit (ICU), expectations are on professionals that are able to identify and interfere on patients' physical alterations, ease the anxiety of family members, use the technological resources that compose this environment, and facilitate interdisciplinary actions. The nurse, as a nursing care coordinator, should provide the maintenance and organization of the environment along with other members of the team.

However, supervising their partners' competence development is constituted of effort and dedicationaimed activities.

Facing the imposed work complexity and demand to an ICU nurse, it is necessary to develop leadership, which is currently an extremely required management competence. Yet, in an interactive environment where decisions must be fast and assertive, in many cases, a demanding position is observed, as opposed to one that is participative.

Also, each nursing team member presents a peculiar characteristic. Some may have graduated recently and have no experience in health care, others already hold practice skills, but are, nonetheless, unprepared to perform more complex nursing actions. Moreover others are already able to perform the prescribed interventions. The nurse, under this context, should adapt his/her leadership style to these differences and ensure assistance to reach the settled targets. Therefore, Situational Leadership has been chosen in this study to evaluate the leadership style facing another member of the team.

Theoretical reference of Situational Leadership is based on a premise stating that there is no single appropriate leadership style for each and every situation. Emphasis sets over leading behavior relating the subordinated team facing an specific task ${ }^{(1)}$. There is an interaction among the amount and direction of orientation (task behavior) provided by the leader, the level of socioemotional support (relationship behavior) provided by the leader and the level of subordinated team member promptness (maturity) while performing a task, function or specific objective $^{(2-3)}$.

Task is defined as the way a leader manages people, telling them what to do, when, where, and how to do it. It means establishing objectives and defining roles. As for relationship behavior, bilateral communication with support and encouragement is observed. Implying active listening and support to collaborators' efforts. Yet, maturity is related to the ability and disposition of some people to manage their own attitudes. The authors include two dimensions in this concept, for instance: work maturity (capability) centered on technical and psychological abilities (disposition) in other words, motivation to do something. These must only be considered when relating to the performance of a specific task ${ }^{(2-3)}$.

In situational leadership four leadership styles are classified: determining, persuading, sharing and delegating, which all involve a behavior combination of task and relationship ${ }^{(1)}$. Subordinated team member maturity is presented by a constant (immature/mature) under four levels: low, low to moderate, moderate to high, and high $^{(1)}$.

Therefore, there is no single best way to influence people. Leadership style will depend on subordinated team member maturity. As the leader employs a leadership style, he may determine a low level maturity to the subordinated team member, relating the specific task, using high behavior for task and low behavior for relationship, in other words, he defines what to do, how, when and where to do it ${ }^{(2-3)}$.

Employing the persuading leadership style, suitable for subordinated team members under low and moderate maturity level, the leader tries to convince him/her to determine the activity according to his/her orientations. Implying high behavior, both for task and relationship ${ }^{(2-3)}$.

The sharing style is the most appropriate when subordinated team member maturity level is between moderate and high. The leader supports efforts and they both participate on the process and on decision making. This style involves high relationship and low task behavior ${ }^{(2-3)}$.

Delegating may be applied when the subordinated team member holds a high maturity level facing a specific task. In this style, the subordinated team member decides how, when and where to perform things, implying low behavior level for both task and relationship ${ }^{(2-3)}$.

Inside the ICU environment, where patients are under a critical state and require fast and agile intensive nursing care performance, there is a strong tendency on leaders to determine actions instead of delegating. Which are the leadership styles used by nurses in the ICU? Is there a relation between the personal and professional profile of nurses and the adopted leadership style? Therefore, the objective of this study is to verify the relation between leadership styles and personal and professional profile of a nurse facing another team member when performing ICU patient care.

\section{METHODS}

This is regarding the descriptive and transversal study performed in the ICU of Disciplina de Dor, Anestesiologia e Terapia Intensiva (Subject: Pain, Anesthesiology and Intensive Care) of Hospital São Paulo at Universidade Federal de São Paulo - UNIFESP. This ICU holds 16 beds aimed at surgical and clinic patients, mainly surgical.

Sample were collected from seven ICU nurses and seven practical nurses according to the following inclusion 
criteria: holding at least a six-moth experience in ICU; accepting to participate on the study by their own free will; working day shifts, since the researcher was unavailable to collect data during night shifts; being present on the three-month period of data collection, in other words, no vacation, maternity/paternity, festivity or health problems leave of absence.

Data collection was performed between March $3^{\text {rd }}$ to June $7^{\text {th }} 2005$, after being approved by the Research Ethics Committee of UNIFESP and obtaining written consent from the participants.

The nurses that agreed on participating in this study raffled a member from the practical nurses team under their supervision and, providing that both agreed on working together, constituted a working pair.

Personal and professional profile data were obtained both from nurses and practical nurses.

During the data collection period, performed twice a day, after identifying the admitted patients in the last 24 hours, the nurse's leadership style was verified through an interview with the following question: "Regarding this patient, what leadership style would you use in case your team partner had to take car of him?" This question was asked to all partners whenever a new patient was admitted.

Concerning the collected data, the situational leadership style and the maturity level classification validated in another study ${ }^{(4)}$ were used.

Sentences exemplifying leadership styles were: E1 (determining): "gives specific instructions and sharply supervises performance"; E2 (persuading): "explain decisions providing clarification opportunities"; E3 (sharing): "shares ideas and the decision process"; E4 (delegating): "grants responsibility for decisions and implementing."

The maturity level of the subordinated team members was evaluated according to the following nursing activities: monitoring and control, medicine administration, hygiene procedures, drain care, patient mobilization and positioning care, and endotracheal tube or tracheostomy tube care. These activities were chosen since they are the most commonly performed by practical nurses while attending on ICU admitted patients, referencing the authors' professional experience on the subject. In order for that, a numbered scale was used from M1 to M4 (M1 to M2 reasonable, M3 quite and M4 totally) where the considered phrases were: this subordinated team member is capable (has the knowledge and the necessary ability); this subordinated team member shows disposition (necessary reliability and dedication) for performing the described nursing procedures. During the data collection period, this question was made only once to the nurse.

Data were analyzed by means of descriptive statistics, and, to verify the personal and professional profile association to the nurse's leadership style, the Tukey multiple comparison analysis holding a significance level of $\mathrm{p}<0.05$ was used.

The adopted referential analysis was that of Situational Leadership ${ }^{(2)}$ theory developers.

\section{RESULTS}

Among the seven nurses (leaders) and the seven practical nurses (subordinated team members) that constituted the working pairs, four worked in the morning shift and three in the afternoon. Among all participants, 13 were female, with an average age of 25.2 (minimum 20; maximum 30 and $\mathrm{dp} \pm 2.8$.) The average time as a registered nurse was of 3.8 years (minimum 1.2; maximum 10.0 and $\mathrm{dp} \pm 2.6$ ), with an average institution working time of 2.4 years (minimum 0.5 ; maximum 5.3 and $\mathrm{dp} \pm 1.6$;) and the average working time in the ICU of 2.0 years (minimum 0.5; maximum 5.3 and $\mathrm{dp} \pm 1.5$ ). All participants acquired knowledge about the theme leadership on undergraduate courses or on practical Nurse courses. Four professionals also had contact with the subject through lectures, two through training programs and two through other sources. Six nurses had taken specialization courses, where five were in ICU and one in management.

When evaluating only one member of the team considering the 87 patients admitted throughout the data collection period, the nurses adopted the following leadership styles as shown in the Chart 1.

Chart 1 - Leadership styles of ICU nurses and maturity of the subordinated team members - Hospital São Paulo $-2005$

\begin{tabular}{|c|r|r|r|r|c|c|}
\hline \multirow{2}{*}{ Partners } & \multicolumn{3}{|c|}{ Leadership Styles } & \multicolumn{2}{c|}{ Subordinated members' maturity } \\
\cline { 2 - 7 } & E1 & E2 & E3 & E4 & Capability & Disposition \\
\hline $\mathbf{1}$ & 1 & 31 & 55 & - & M2 & M3 \\
\hline $\mathbf{2}$ & 5 & 39 & 43 & - & M2 & M2 \\
\hline $\mathbf{3}$ & 46 & 2 & 39 & - & M2 & M4 \\
\hline $\mathbf{4}$ & 25 & 34 & 27 & 1 & M3 & M2 \\
\hline $\mathbf{5}$ & 43 & 44 & - & - & M1 & M1 \\
\hline $\mathbf{6}$ & 39 & 39 & 7 & 2 & M3 & M3 \\
\hline $\mathbf{7}$ & 11 & 39 & 37 & - & M3 & M3 \\
\hline
\end{tabular}

According to Table 1, nurses have performed a higher frequency of E2 style, followed by E1 and E3, in other words, persuading, determining and sharing, with their subordinated team members while performing the nursing activities established to the 87 patients admitted to the ICU. The seven practical nurses featured a higher 
frequency of maturity classified as reasonable (M2), quite (M3) for capability and quite (M3) for disposition.

All variables related to personal and professional profile were not statistically associated to the chosen leadership styles by nurses $(\mathrm{p}>0.05$.)

\section{DISCUSSION}

The sample's personal and professional profile in this study reveals that $92.8 \%$ were young males. The nurses had less graduation time than practical nurses; however they had been working for longer periods in the institution. ICU working time was the same between leaders and subordinated team members. All of them had some contact with the theme leadership and six nurses had taken specialization courses.

All of these variables did not present significant statistics relation to the chosen leadership styles $(\mathrm{p}>0.05$.) The fact that leaders were young and held a short professional experience might have justified style E1 (determining) and E2 (persuading) stands out, perhaps due to the need of ensuring leadership performance, since the subordinated team members held reasonable to quite maturity. This verification might have been observed, in case the sample was of a higher number and if personal and professional variables could have been statistically associated to style preference.

Results also evidence a tendency on a more participative leadership performance along with persuading (E2) and sharing (E3) on attending decision making with the subordinated team members. However, the determining (E1) mode still persists. One of the possibilities is the concern about immediate results needed to be reached over severely ill patient care.

The subordinated team members present maturity levels between M2 and M3 both for capability and disposition, in other words, they are individuals able to perform the prescribed activities, however, they need motivation from the leader in order to achieve assistance targets.

Studies that have used Situational Leadership have found similar data in various hospital units. However, their methodology are related to the opinion relation of leadership styles performed by the nurse and the leadership style that this professional should adopt, regarding the maturity level of the subordinated practical nurse, facing the developed assistance activities in the unit. In the ER, the E3 (sharing) style was highly performed by nurses ${ }^{(5)}$. A similar fact also was observed in the surgical center ${ }^{(6)}$. In the surgical admittance unit styles E3 (sharing) and E4 (delegating) ${ }^{(7)}$ were more used. However, when comparing the same sector in two different hospitals, E1 (determining) along with E2 (persuading) and E3 (sharing) ${ }^{(4)}$ have prevailed.
Therefore, the styles are adopted in various situations depending on the variables involved: task, relationship and maturity. There is no single best way to influence people ${ }^{(8)}$. Leadership style will depend on subordinated team maturity.

Situational Leadership may also be applied in various knowledge areas as education, for instance. The study that aimed at analyzing leadership of nurses in charge of teaching administration, under the observation of subordinated team members (graduation students), E3 ( sharing) and E2 ( persuading) styles were observed to be practiced ${ }^{(9)}$. In addition, another author has alleged the use of such theoretical reference for teachers, in other words, nurses that perform in the clinical practice teaching-learning process of graduation students.

In order to identify the leadership style of nursing directors, situational leadership ${ }^{(11)}$ was also used. Results evidence that E2 (persuading) and E3 (sharing) were established as the main and secondary styles, respectively, a fact also presented by the other study ${ }^{(12)}$ when considering the nurses of a philanthropic hospital.

Therefore, situational leadership has become an application model for leadership performance of nurses when managing people, since it considers the live context and the maturity and disposition of the subordinated team member to coordinate nursing care.

Since the ICU is an interactive environment, where decision-making is continuous, professionals need to be prepared for the use of this competence.

However, studies ${ }^{(13-14)}$ demonstrate that leadership teaching in learning institutions, throughout graduation courses, was not enough for the investigated nurses. It is well known that this has to be a continuous process, initiated during graduation courses and constantly worked by the nurse, aiming at reaching the requirements of the institutions, as well as to promote professional and personal satisfaction.

Intending to contribute on nurses' leadership preparation, a continued education program was elaborated to develop private general hospital nurses' leadership and communication potential, by the use of situational leadership. The subjects of this study have positively evaluated the program's contributions, and have verified an application feasibility of situational leadership into nursing ${ }^{(15)}$ routine activities.

Therefore, the situational leadership application has provided, to leaders, a higher expertise on executing this competence in their managing activities. However, it is well-know that this is not the best way. It is the nurse's role to constantly improve, in order to allow new methodologies to appear, answering collaborators, institutions and also the requests of their own convictions. 


\section{CONCLUSION}

Nurses have performed, more frequently, style E2 (persuading), followed by E1 (determining) and E3 (sharing) over the subordinated team members, regarding the ICU nursing activities. The seven practical nurses featured a higher frequency of maturity classified as reasonable (M2) and quite (M3) for capability and quite (M3) for disposition. All variables related to personal and professional profile were not statistically associated

\section{REFERENCES}

1. Galvão CM, Trevizan MA, Sawada NO, Coleta JAD. Liderança situacional: estrutura de referência para o trabalho do enfermeiro-líder no contexto hospitalar. Rev Latinoam Enferm. 1998; 6(1):81-90.

2. Hersey P, Blanchard KH. Psicologia para administradores: teoria e as técnicas da liderança situacional. São Paulo: Epu; 1986.

3. Galvão CM. Liderança situacional: uma contribuição ao trabalho do enfermeiro-líder no contexto hospitalar [tese]. Ribeirão Preto: Escola de Enfermagem de Ribeirão Preto da Universidade de São Paulo;1995.

4. Galvão CM, Trevizan MA, Sawada NO, Fávero N. O estilo de liderança exercido pelo enfermeiro de unidade de internação cirúrgica sob o enfoque da liderança situacional. Rev Latinoam Enferm. 1997; 5(2):39-47.

5. Wehbe G. Liderança situacional: um modelo para aplicação pelo enfermeiro de unidade de emergência junto à equipe de enfermagem [dissertação]. Ribeirão Preto: Escola de Enfermagem de Ribeirão Preto da Universidade de São Paulo; 2004.

6. Trevizan MA. Liderança do enfermeiro: o ideal e o real no contexto hospitalar. São Paulo: Sarvier;1993.

7. Galvão CM, Trevizan MA, Sawada NO, Mendes IAC. Enfermeiro cirúrgico: seu estilo de liderança com o pessoal auxiliar de enfermagem. Rev Gauch Enferm. 1997; 18(1):31-42. in significant ways to the chosen leadership styles by nurses $(\mathrm{p}>0.05$.)

The ICU nurse, in order to promote human resources management in the Nursing area, needs to know the capabilities and disposition of collaborators and connect them to the complexity level required by customers. Therefore, the team professionals will be able to grow and improve their knowledge, abilities and attitudes on nursing care development. It is a continuous process, requiring profound dedication to achieve such results.

8. Galvão CM, Trevizan MA, Sawada NO, Mendes IAC. Liderança situacional: um modelo para aplicação na enfermagem brasileira. Rev Esc Enferm USP. 1997; 31(2):227-36.

9. Goldenberg D. Nursing education leadership. Effect of situational and constraint variables on leadership style. J Adv Nurs. 1990; 15(11):1326-34.

10. Lockwood-Rayermann S. Preceptor leadership style and the nursing practicum. J Prof Nurs. 2003; 19(1):32-7.

11. Adams CE. Leader behavior in rural directors of nurses. J Nurs Adm. 1993; 23(9):29-34.

12. Lourenço MR, Trevizan MA. Liderança situacional: análise de estilo de enfermeiros-líderes. Acta Paul Enferm. 2002; 15(1):48-52.

13. Simões ALA. O ser líder no cotidiano do profissional enfermeiro [dissertação]. Ribeirão Preto: Escola de Enfermagem de Ribeirão Preto da Universidade de São Paulo; 1997.

14. Castro AP, Galvão CM, Sawada NO. Liderança e comunicação: construção de instrumento de medida para alunos de graduação em enfermagem. Rev Gauch Enferm. 1999; 20(2):77-89.

15. Galvão CM, Sawada NO, Castro AP, Corniani F. Liderança e comunicação: estratégias essenciais para o gerenciamento da assistência de enfermagem no contexto hospitalar. Rev Latinoam Enferm. 2000; 8(5):34-43. 